\title{
Seroprevalence of transfusion transmissible viral infections among blood donors in a tertiary care hospital
}

\author{
C Dhinesh Kumar", VK Panicker, RS Febe, R Krishnamoorthy \\ From First International Science Symposium on HIV and Infectious Diseases (HIV SCIENCE 2012) \\ Chennai, India. 20-22 January 2012
}

\section{Introduction}

Timely transfusion of blood saves millions of lives but unsafe transfusion practices puts many people at risk of transfusion transmissible infection (TTI). TTI can exist as an asymptomatic disease in the host; so, donors must be screened for high risk behaviour related diseases.

\section{Aim}

To estimate the seroprevalence of HIV, HBsAg and HCV among whole blood donors.

\section{Methodology}

This study was conducted at Department of Transfusion Medicine, Sri Ramachandra University, Porur; Chennai during Jul-2010 to Jun-2011. The sample size in this study was 11,871 . All samples were subjected to ELISA screening for anti-HIV $1 \& 2, \mathrm{HBsAg}$ and anti-HCV in addition to other mandatory tests.

\section{Results}

Out of 11,871 samples, seroprevalence of HIV, HBsAg and $\mathrm{HCV}$ were estimated to be $0.05 \%, 1.58 \%$ and $0.13 \%$ respectively during the study period.

\section{Conclusion}

Stringent screening of donors for TTI is crucial to ensure safe supply of blood and blood products. This study involved both voluntary and replacement donors. Prevalence of TTI was found to be low in females. Highly sensitive ELISA kits play a major role in detecting antibody to HIV, HCV and HBsAg. Furthermore, Nucleic Acid Testing (NAT) facilitates viral detection at

\footnotetext{
* Correspondence: drdhinesh@gmail.com
}

Sri Ramachandra University, Department of Transfusion Medicine, Chennai, India
Submit your next manuscript to BioMed Central and take full advantage of:

- Convenient online submission

- Thorough peer review

- No space constraints or color figure charges

- Inclusion in PubMed, CAS, Scopus and Google Scholar

- Research which is freely available for redistribution
- Immediate publication on acceptance 